\title{
Comparison of Three Commonly Used Equations for Calculating Local Scour Depth around Bridge Pier under Ice Covered Flow Condition
}

\author{
Mohammad Reza Namaee, Yuquan Li, Jueyi Sui*, Todd Whitcombe \\ Environmental Engineering Program, University of Northern British Columbia, Prince George, Canada \\ Email: *jueyi.sui@unbc.ca
}

How to cite this paper: Namaee, M.R., Li, Y.Q., Sui, J.Y. and Whitcombe, T. (2018) Comparison of Three Commonly Used Equations for Calculating Local Scour Depth around Bridge Pier under Ice Covered Flow Condition. World Journal of Engineering and Technology, 6, 50-62.

https://doi.org/10.4236/wjet.2018.62B006

Received: January 30, 2018

Accepted: May 19, 2018

Published: May 22, 2018

\begin{abstract}
A precise prediction of maximum scour depth around bridge foundations under ice covered condition is crucial for their safe design because underestimation may result in bridge failure and over-estimation will lead to unnecessary construction costs. Compared to pier scour depth predictions within an open channel, few studies have attempted to predict the extent of pier scour depth under ice-covered condition. The present work examines scour under ice by using a series of clear-water flume experiments employing two adjacent circular bridge piers in a uniform bed were exposed to open channel and both rough and smooth ice covered channels. The measured scour depths were compared to three commonly used bridge scour equations including Gao's simplified equation, the HEC-18/Jones equation, and the Froehlich Design Equation. The present study has several advantages as it adds to the understanding of the physics of bridge pier scour under ice cover flow condition, it checks the validity and reliability of commonly used bridge pier equations, and it reveals whether they are valid for the case of scour under ice-covered flow conditions. In addition, it explains how accurately an equation developed for scour under open channel flow can predict scour around bridge piers under ice-covered flow condition.
\end{abstract}

\section{Keywords}

Ice Cover, Local Scour, Bridge Piers, Maximum Scour Depth

\section{Introduction}

Scouring can be defined as the process by which the particles of soil or rock 
around an abutment or pier of a bridge get eroded and removed to a certain depth (called the scour depth) [1]. The U.S. Federal Highway Administration (FHWA) has estimated $60 \%$ of bridge failure cases in the USA are due to scour and on average, approximately 50 to 60 bridges collapse annually in the USA [2]. Wardhana \& Hadipriono [3] studied 500 failures of bridge structures in the United States between 1989 and 2000 and reported that the most frequent causes of bridge failures were due to floods, scour, and their cumulative impact. The average age of the 500 failed bridges was 52.5 years but ranged from 1 to 157 years old [4]. Brice \& Blodgett [5] reported that damages to bridges and highways from major regional floods in 1964 and 1972 were equivalent to approximately 100 million US dollars per event. Bridge foundations should be designed to withstand the effects of scour. Bridge damage and failure have huge negative social and economic impacts in terms of reconstruction costs, maintenance and monitoring of existing structures, the disruptions of traffic flow, and in some life-threatening cases, the cost of human lives [4]. Moreover, a precise prediction of scour depth will not only help to prevent those bridge failures which are the consequence of under-estimation of scour depth but also will efficiently reduce unnecessary construction cost of those bridge piers in which scour depths are over-estimated. To safely design bridges located on waterways under severe flooding conditions, many researchers have developed a number of laboratory-derived equations for predicting bridge pier scour depth [6] [7] [8] [9] [10] [11] [12]. These equations are mostly empirical formulae which are usually based on regressional analysis of laboratory and/or field scour data. However, they differ from each other in terms of the factors considered in constructing the scour model, parameters used in the equation, laboratory and/or site conditions. Since the number of these equations is relatively large, selection of the best performing equations for a special case is a difficult task. Comparison studies of scour formulae especially for different flow conditions might be helpful to select the one with the best performance. Additionally, many rivers become ice-covered during the winter months. However, the winter season is often overlooked even though most rivers in Canada and northern parts of the United States, Europe, and Asia are annually affected by ice. The relatively smaller number of studies on the scour around bridge pier under ice-covered flow condition is due to the inherent difficulty in collecting field data while ice is present and complications in lab-based measurements as a result of different scales and of temperature effects [13]. Ice cover can significantly change the flow field and impact sediment transport in natural rivers. The formation of a stable ice cover effectively doubles the wetted perimeter compared to open channel conditions. This alters the hydraulics of the channel by imposing an extra boundary to the flow, causing the velocity profile to be shifted towards a smoother boundary (channel bed) and adding to the flow resistance [14]. Furthermore, ice cover can lead to issues such as ice jamming, flooding, restricting the generation of hydro-power, blocking river navigation, and affecting the overall ecosystem bal- 
ance [15]. One of the latest studies on bridge pier scour under ice-covered flow condition was conducted by Hirshfield [16]. These experiments were conducted in a large-scale flume to study the impact of ice cover roughness and non-uniformity of sediment on the local scour around a single circular bridge pier under open channel, smooth ice and rough ice covered conditions. It was concluded turbulence intensity was greater under ice covered than open channel conditions. In addition, it was observed that local pier scour under rough and smooth ice cover was on average 37 and 20 percent greater than open channel scour depth, respectively [16]. Another significant study on local Scour around bridge piers under ice-covered conditions was carried out by $\mathrm{Wu}$ et al. [17]. In this study, the scour profile under an ice cover is compared with previous studies by examining the role of relative bed coarseness, flow shallowness, and pier Froude number. It was concluded the scour depth under an ice-covered conditions is larger than under open channel flow conditions. Further, the presence of the ice cover becomes more significant with respect to scour at shallower flow depths [17].

\section{Materials and Methods}

Most of the equations for the prediction of bridge pier scouring express the final scour depth as a function of the flow characteristics (mean flow velocity at the approach section, water depth), flow properties (density and viscosity of the fluid), stream bed material properties (mean particle diameter, density) and bridge geometry (shape and dimension of the pier, angle of attack of the flow). In this paper, scour around circular bridge piers will be experimentally examined and subsequently the validity and reliability of three of the more commonly used and cited scour equations developed specifically for open channel flow condition will be investigated to see how accurately they predict scouring around bridge piers under ice-covered flow conditions.

\subsection{HEC-18/Jones Equation}

The most commonly used pier scour equation in the United States is the Colorado State University (CSU) equation proposed by Richardson and Davis [18] and is recommended by the U.S. Department of Transportation's Hydraulic Engineering (HEC-I8) (1993). It was developed from laboratory data and is recommended for both live-bed and clear-water conditions. The HEC-18/Jones equation is based on the Colorado State University (CSU) equation:

$$
y_{s} / y_{0}=2 K_{1} K_{2} K_{3} K_{4}\left(b / y_{0}\right)^{0.65} F^{0.43}
$$

where $y_{s}=$ scour depth; $y_{0}=$ the approach flow depth; $y_{s} / y_{0}$ is a dimensionless expression of the relative scour depth with respect to flow depth; $K_{1}=$ correction factor for pier nose shape which is unity for circular cylinder; $K_{2}=$ correction factor for angle of attack flow which is unity for $90^{\circ} ; K_{3}=$ correction factor for bed condition which is 1.1 for clear water scour; $b=$ nominal pier width; and $F r=$ approach flow Froude number. $K_{4}$ is a correction factor to account for armoring 
of the scour hole:

$$
K_{4}=\left[1-0.89\left(1-V_{R}\right)^{2}\right]^{0.5}
$$

where $V_{R}$ is the velocity ratio and is dimensionless:

$$
V_{R}=\left[\frac{V_{0}-V_{i 50}}{V_{c 90}-V_{i 50}}\right]
$$

where $V_{o}$ is the approach velocity directly upstream from the pier and $V_{\mathrm{i} 50}$ is the approach velocity, in feet per second, required to initiate scour at the pier for the particle size $D_{50}$. $V_{50}$ is calculated as follows:

$$
V_{i 50}=0.645\left[\frac{D_{50}}{b}\right]^{0.053} V_{c 50}
$$

where $D_{50}$ is the particle size for which 50 percent of the bed material is finer, in units of feet and $V_{c 50}$ is the critical velocity, in feet per second, for incipient motion of the particle size $D_{50} . V_{c 50}$ is defined as follows:

$$
V_{c 50}=11.21 y_{0}^{1 / 6} D_{50}^{1 / 3}
$$

while $D_{90}$ is the particle size for which 90 percent of the bed material is finer, in units of feet, and $V_{c 90}$ is the critical velocity, in feet per second, for the incipient motion of the particle size as given by:

$$
V_{c 90}=11.21 y_{0}^{1 / 6} D_{90}^{1 / 3}
$$

\subsection{Gao's Simplified Equation}

Gao's simplified pier scour equation is based on laboratory and field data from China [19]. This equation has different forms depending upon whether the scour condition is live-bed scour (bed material upstream from bridge is in motion) or clear-water scour (bed material upstream from bridge is not in motion) as discussed in Landers \& Mueller [20]. The Gao's simplified equation for clear-water pier scour is defined as [19]:

$$
y_{s}=1.141 K_{s} b^{0.6} y_{0}^{0.15} D_{m}^{-0.07}\left(\frac{V_{0}-V_{i c}}{V_{c}-V_{i c}}\right)
$$

where $y_{s}$ is the depth of pier scour below the ambient bed, in feet; $K_{s}$ is the simplified pier shape coefficient which is 1.0 for cylinders; $b$ is the width of bridge pier, in feet; $y_{0}$ is the depth of flow directly upstream from the pier, in feet; $D_{m}$ is the mean particle size of the bed material, in feet (for this study $D_{50}$ was used as $\left.D_{m}\right) ; V_{o}$ is the approach velocity directly upstream from the pier, in feet per second; and $V_{c}$ is the critical (incipient motion) velocity, in feet per second, for the $D_{m}$-sized particle. $V_{i c}$ is the approach velocity, in feet per second, corresponding to critical velocity at the pier. $V_{i c}$ can be calculated using the following equation:

$$
V_{i c}=0.645\left(\frac{D_{m}}{b}\right)^{0.053} V_{c}
$$

If the density of water is assumed to be 62.4 pounds per cubic foot and the bed 
material is assumed to have a specific gravity of 2.65 , the equation for $V_{c}$ can be expressed as:

$$
V_{c}=3.28\left(\frac{y_{0}}{D_{m}}\right)^{0.14}\left(8.85 D_{m}+6.05 E^{-7}\left[\frac{10+0.3048 y_{0}}{\left(0.3048 D_{m}\right)^{0.72}}\right]\right)^{0.5}
$$

\subsection{Froehlich Design Equation}

The Froehlich design equation is included as a pier-scour calculation option within the computer model HEC-RAS, Version 3.1 [21]. The Froehlich's [22] design equation is defined as:

$$
y_{s}=0.32 b \phi F r_{1}^{0.2}\left(\frac{b_{e}}{b}\right)^{0.62}\left(\frac{y_{0}}{b}\right)^{0.46}\left(\frac{b}{D_{50}}\right)^{0.08}+b
$$

where $\phi$ is a dimensionless coefficient based on the shape of the pier nose, and is 1.0 for round-nosed piers; $F r_{1}$ is the Froude Number directly upstream from the pier; $b_{e}$ is the width of the bridge pier projected normal to the approach flow, in feet; $b$ is the width of the bridge pier, in feet; $D_{50}$ is the particle size for which 50 percent of the bed material is finer, in feet and $y_{0}$ is the depth of flow directly upstream from the pier, in feet.

\section{Experiment Setup}

Experiments were carried out at the Quesnel River Research Centre, Likely, BC, Canada in a large-scale flume. The flume measures $40 \mathrm{~m}$ long, $2 \mathrm{~m}$ wide and $1.3 \mathrm{~m}$ deep. The longitudinal slope of the flume bottom was 0.2 percent. A holding tank with a volume of nearly $90 \mathrm{~m}^{3}$ was located at the upstream end of the flume and provided a constant head in the experimental zone. Two valves were connected to the holding tank to allow for control of the flow velocity. At the end of the holding tank and upstream of the main flume, water overflowed from a rectangular weir into the flume. Since the flow of water was turbulent while entering the flume, a flow diffuser was placed downstream of the rectangular weir to dissipate the turbulence in the flow of water. Two sand boxes with the depth of $0.30 \mathrm{~m}$ were filled with a uniform sediment having a median particle size $\left(\mathrm{D}_{50}\right)$ of $0.47 \mathrm{~mm}$. The first sand box was $5.6 \mathrm{~m}$ in length and the second sand box was $5.8 \mathrm{~m}$ in length. The distance between the sand boxes was $10.2 \mathrm{~m}$. Four different pairs of bridge piers with diameter of $6 \mathrm{~cm}, 9 \mathrm{~cm}, 11 \mathrm{~cm}$ and 17 $\mathrm{cm}$ were used (Figure 1(a)). Bridge piers were constructed from PVC plumbing pipe and were circular in shape. A pair of bridge piers were placed inside both sand boxes at a distance of $50 \mathrm{~cm}$ from each other and were fixed to the bottom of the flume. One pair of bridge piers were located in each sand box so two experiments were carried out simultaneously in each experimental run. Each pier was offset from the centre line by $25 \mathrm{~cm}$, as illustrated in Figure 1(b). The water depth in the flume was adjusted by the position of the tailgates. In front of the first sand box, a SonTek Incorporated 2D flow meter was installed to measure the approaching flow velocity, water depth, and inflow discharge during the experiment. A staff gauge was also installed in the middle of each sand box 


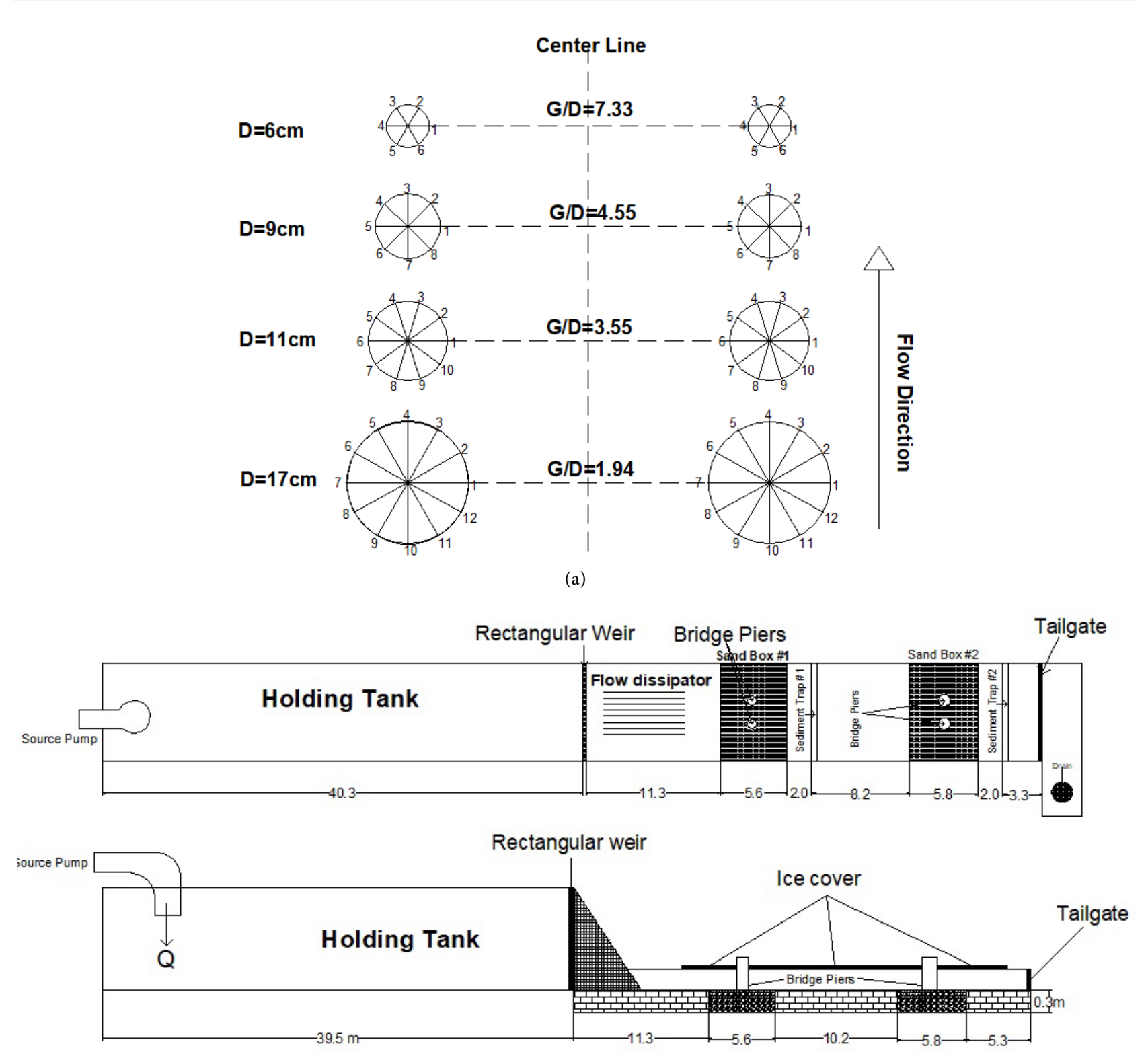

(b)

Figure 1. Experimental setup-plan and lateral views, respectively.

to manually verify water depth. The scour hole velocity field was measured using a 10-Mhz Acoustic Droppler Velocimeter (ADV) by SonTek. In order to simulate ice cover, 13 panels of Styrofoam with dimensions of $1.2 \mathrm{~m} \times 2.4 \mathrm{~m}(4 \times 8$ foot) were used to cover nearly the entire surface of flume. Styrofoam density was $0.026 \mathrm{gr} / \mathrm{cm}^{3}$ and the Styrofoam was floated on the surface in the flume during the experimental runs. In the present study, two types of model ice cover were used, namely smooth cover and rough cover. The smooth ice cover was the surface of the original Styrofoam panels while the rough ice cover was made by attaching small Styrofoam cubes to the bottom of the smooth cover. The dimensions of Styrofoam cubes were $2.5 \mathrm{~cm} \times 2.5 \mathrm{~cm} \times 2.5 \mathrm{~cm}$ and were spaced $3.5 \mathrm{~cm}$ apart for the Styrofoam covering panels which were placed above the sand boxes 
and were spaced $5.5 \mathrm{~m}$ apart for the rest of the Styrofoam covering panels outside of the sand boxes. 36 experiments were conducted under open channel, smooth and rough ice conditions. Figure 2 shows the rough ice-covered flow around a bridge pier in experiment as well as ADV measurement around scour depth. The experimental runs were 24 hours long which allowed the scour hole to reach an equilibrium depth as noted in previous experiments conducted by Hirshfield [16]. After 24 hours, the flume was gradually drained. The scour depth was manually measured along the outside lines of the circular bridge piers.

\section{Results and Discussion}

Maximum scour depths calculated by the above three pier-scour equations were compared to 36 sets of experimental data. In this section, comparisons between the results from each equation and the experimental results are discussed along with an Error analysis including RMSE (Root Mean Squared Error), Index of Agreement $\left(I_{a}\right)$ and MAE (Mean Absolute Error). The Absolute Error (MAE); Root Mean Square Error (RMSE) and Index of Agreement $\left(I_{a}\right)$ are mathematically described by the following equations:

$$
\begin{gathered}
\text { MAE }=\frac{\sum_{i=1}^{n}\left|e_{i}\right|}{n} \\
\mathrm{RMSE}=\sqrt{\frac{\sum_{i=1}^{n}\left(y_{i}-x_{i}\right)^{2}}{n}} \\
I_{a}=1-\frac{\sum_{i=1}^{n}\left(y_{i}-x_{i}\right)^{2}}{\sum_{i=1}^{n}\left(\left|x_{i}-\bar{x}\right|+\left|y_{i}-\bar{x}\right|\right)^{2}}
\end{gathered}
$$

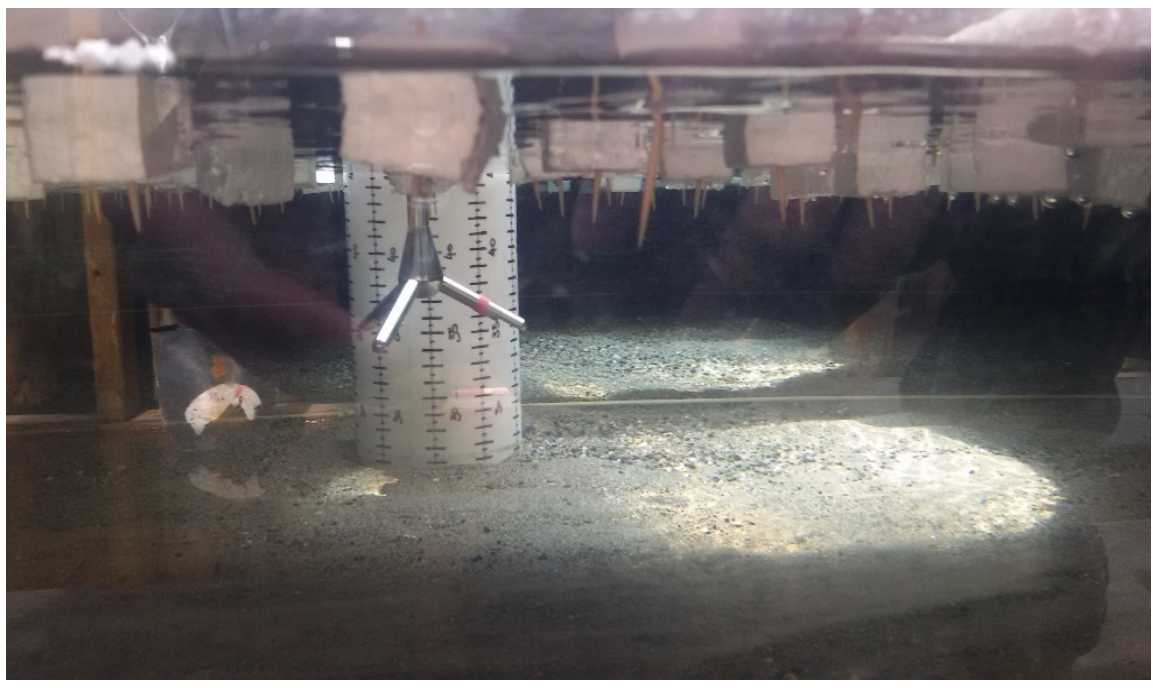

Figure 2. 10-Mhz Acoustic Droppler Velocimeter in use to measure the velocity field around bridge piers under rough ice-covered flow conditions. 
where $x_{i}$ is scour depth obtained from experiments and $y_{i}$ is the corresponding predicted scour depths; $\bar{x}$ is the mean experimental scour depth and $n$ is number of records. Smaller values of MAE and RMSE indicate a more successful prediction. The Index of Agreement $\left(I_{a}\right)$ is a standardized measure of the degree of model prediction error and varies between 0 and 1 . A value of 1 indicates a perfect match, while 0 indicates no agreement [23].

Table 1 demonstrates the performance of the Gao's simplified equation (SCE), the HEC-18/Jones equation (HJE) and Froehlich Design Equation (FDE) under smooth and rough flow conditions. The measured scour in Table 1 stands for the maximum scour depth between left and right bridge pier. Table 2 provides

Table 1. Comparison of calculated pier scour to measured pier scour from three equations.

\begin{tabular}{|c|c|c|c|c|c|c|c|c|}
\hline \multirow{3}{*}{ Cover } & & & \multicolumn{6}{|c|}{ Equation } \\
\hline & \multirow{2}{*}{$\begin{array}{c}\text { Pier } \\
\text { dentification }\end{array}$} & \multirow{2}{*}{$\begin{array}{l}\text { Measured } \\
\text { Scour (ft.) }\end{array}$} & \multicolumn{2}{|c|}{ Gao's simplified } & \multicolumn{2}{|c|}{ Froehlich Design } & \multicolumn{2}{|c|}{ Hec-18/Jones } \\
\hline & & & $\begin{array}{l}\text { Calculated } \\
\text { scour (ft.) }\end{array}$ & $\begin{array}{c}\text { Residual } \\
\text { (ft.) }\end{array}$ & $\begin{array}{l}\text { Calculated } \\
\text { scour (ft.) }\end{array}$ & $\begin{array}{c}\text { Residual } \\
\text { (ft.) }\end{array}$ & $\begin{array}{l}\text { Calculated } \\
\text { scour (ft.) }\end{array}$ & $\begin{array}{c}\text { Residual } \\
\text { (ft.) }\end{array}$ \\
\hline Smooth & Right & 0.10 & 0.06 & -0.03 & 0.28 & 0.19 & 0.24 & 0.15 \\
\hline Smooth & Left & 0.11 & 0.10 & -0.01 & 0.26 & 0.15 & 0.25 & 0.13 \\
\hline Smooth & Right & 0.14 & 0.10 & -0.04 & 0.29 & 0.15 & 0.28 & 0.14 \\
\hline Smooth & Left & 0.10 & 0.11 & 0.01 & 0.40 & 0.30 & 0.33 & 0.23 \\
\hline Smooth & Right & 0.22 & 0.19 & -0.03 & 0.38 & 0.15 & 0.36 & 0.14 \\
\hline Smooth & Left & 0.21 & 0.16 & -0.05 & 0.41 & 0.20 & 0.39 & 0.18 \\
\hline Smooth & Left & 0.14 & 0.08 & -0.06 & 0.47 & 0.33 & 0.33 & 0.20 \\
\hline Smooth & Right & 0.26 & 0.19 & -0.07 & 0.45 & 0.18 & 0.39 & 0.13 \\
\hline Smooth & Left & 0.26 & 0.18 & -0.08 & 0.49 & 0.23 & 0.43 & 0.17 \\
\hline Smooth & Left & 0.10 & 0.08 & -0.02 & 0.71 & 0.61 & 0.42 & 0.33 \\
\hline Smooth & Left & 0.16 & 0.17 & 0.01 & 0.67 & 0.51 & 0.46 & 0.30 \\
\hline Smooth & Left & 0.16 & 0.20 & 0.04 & 0.72 & 0.56 & 0.55 & 0.39 \\
\hline Rough & Left & 0.15 & 0.09 & -0.06 & 0.28 & 0.13 & 0.27 & 0.11 \\
\hline Rough & Right & 0.19 & 0.10 & -0.09 & 0.26 & 0.07 & 0.25 & 0.06 \\
\hline Rough & Left & 0.18 & 0.14 & -0.04 & 0.30 & 0.11 & 0.31 & 0.13 \\
\hline Rough & Right & 0.31 & 0.10 & -0.21 & 0.40 & 0.10 & 0.32 & 0.02 \\
\hline Rough & Right & 0.31 & 0.13 & -0.18 & 0.37 & 0.07 & 0.32 & 0.01 \\
\hline Rough & Left & 0.24 & 0.15 & -0.09 & 0.41 & 0.17 & 0.38 & 0.14 \\
\hline Rough & Left & 0.22 & 0.11 & -0.11 & 0.47 & 0.25 & 0.36 & 0.14 \\
\hline Rough & Right & 0.26 & 0.19 & -0.08 & 0.45 & 0.18 & 0.38 & 0.12 \\
\hline Rough & Right & 0.28 & 0.17 & -0.11 & 0.49 & 0.21 & 0.42 & 0.15 \\
\hline Rough & Left & 0.16 & 0.12 & -0.05 & 0.70 & 0.54 & 0.46 & 0.30 \\
\hline Rough & Left & 0.19 & 0.18 & -0.01 & 0.67 & 0.48 & 0.47 & 0.28 \\
\hline Rough & Right & 0.20 & 0.18 & -0.02 & 0.73 & 0.53 & 0.55 & 0.35 \\
\hline
\end{tabular}


Table 2. Error values of the three equations with respect to measured data under open, smooth and rough flow.

\begin{tabular}{cccccccccc}
\hline & \multicolumn{3}{c}{ RMSE (\%) } & \multicolumn{3}{c}{$I_{a}$} & \multicolumn{3}{c}{ MAE (\%) } \\
\cline { 2 - 9 } & SCE & HJE & FDE & SCE & HJE & FDE & SCE & HJE & FDE \\
\hline Open & 3.58 & 24.88 & 35.50 & 0.90 & 0.48 & 0.34 & 6.8 & 23 & 38 \\
Smooth & 4.38 & 22.33 & 33.91 & 0.84 & 0.56 & 0.41 & 14.1 & 26 & 25 \\
Rough & 10.33 & 18.21 & 29.19 & 0.46 & 0.78 & 0.64 & 15.7 & 45 & 39 \\
\hline
\end{tabular}

a comparison of the predicted maximum scour depth from the three equations to maximum measured scour depth under smooth and rough ice-covered flow condition. It should be mentioned the residual values are defined as predicted scour depth minus measured scour depth. A negative residual value indicates over-estimated scour depth. From the data provided, it is possible to determine which equation is most useful under various conditions. Evaluation of these equations are important to bridge design especially for the case of flow under ice-covered condition.

The scatterplots in Figure 3(a)-(c) compare predicted pier scour depth for each of the three equations to the measured scour depths obtained experimentally under the different flow conditions. Pier-scour depths calculated using the Froehlich design equation exceeded measured scour depths for every measurement of both open channel and ice-covered flows (Figure 3(a), Table 1). Likewise, Pier-scour depths calculated using the HEC-18/Jones equation similarly exceeded measured pier scour for all 36 observations (Figure 3(b) and Table 1). However, overestimations were larger for the Froehlich design than for the HEC-18/Jones equation.

Overall, the most reliable and accurate equation which has predicted the pier scour depths under open channel and ice-covered flow to a very good extent was Gao's simplified equation. Pier-scour depths calculated using the Gao's simplified equation were smaller than measured scour depths for 6 of the 12 measurements for open channel flow and for 9 of the 12 measurements for smooth ice cover. However, it completely underestimated Pier-scour depths for the rough ice cover flow (Figure 3(c) and Table 1). Statistics for calculated and measured pier scour are summarized in Table 2. The averages of pier-scour depths for open channel flow calculated from Froehlich equation was $0.46 \mathrm{ft}$, from the HEC-18/Jones was $0.38 \mathrm{ft}$, and from the Gao's simplified equation was $0.15 \mathrm{ft}$. The average of the measured pier-scour depths was actually $0.15 \mathrm{ft}$. This result indicates Gao's simplified equation was entirely successful in predicting the scour depth under open channel conditions. Both the Froehlich and HEC-18/Jones equations resulted in significant over-estimation of the average scour depth. Furthermore, from Table 2, the highest index of agreement value (Ia) and the lowest RMSE and MAE values are for the Gao's simplified equation for the case of open channel flow.

In terms of smooth ice-covered flow, the averages of pier-scour depths for open channel flow calculated from Froehlich equation was $0.46 \mathrm{ft}$, from the 


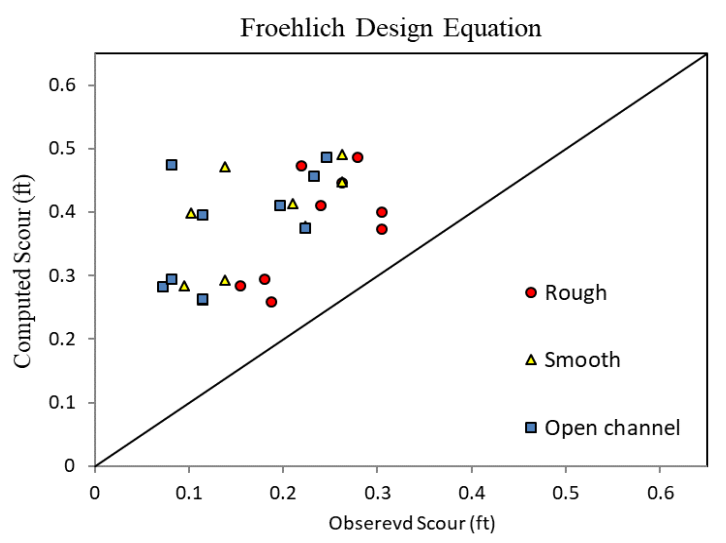

(a)

HEC-18/Jones Equation

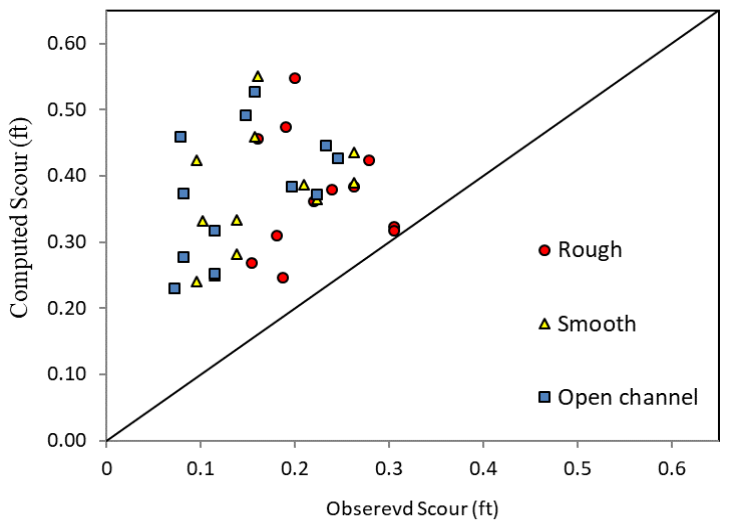

(b)

Simplified Chinese Equation

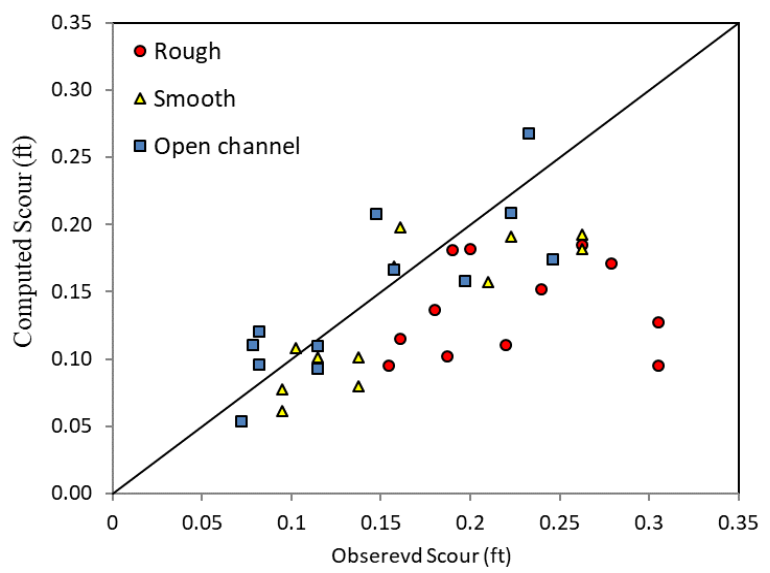

(c)

Figure 3. (a) Comparison of calculated to measured pier scour for Froehlich equation under open, smooth and rough flow condition. (b) Comparison of calculated to measured pier scour for HEC-18/Jones equation under open, smooth and rough flow condition. (c) Comparison of calculated scour depths to the measured scour depth for Gao's simplified equation under open, smooth and rough flow condition. 
HEC-18/Jones was $0.37 \mathrm{ft}$, and from the Gao's simplified equation was $0.13 \mathrm{ft}$. The actual average measured pier-scour depth was $0.16 \mathrm{ft}$ again indicating Gao's simplified equation provided the best agreement with the measured value and was more successful in predicting the scour depth. Both the Froehlich and HEC-18/Jones equations resulted in the significant over-estimation of the scour depth on average. The highest index of agreement value (0.84) and the lowest RMSE and MAE values were obtained with Gao's simplified equation under the smooth ice-covered flow condition.

In terms of rough ice-covered flow, the averages of pier-scour depths for open channel flow calculated from Froehlich equation was $0.46 \mathrm{ft}$, from the HEC-18/Jones was $0.37 \mathrm{ft}$, and from the Gao's simplified equation was $0.14 \mathrm{ft}$. In this case, the rough ice surface increased the average measured pier-scour depths to $0.22 \mathrm{ft}$ which is higher than the average scour depth calculated using Gao's simplified equation. However, the results from Gao's equation were closer to the experimental results than either the Froehlich or the HEC-18/Jones equation might suggest it was more successful in calculating scour depth. Further, the highest index of agreement value (0.78) and the lowest RMSE and MAE values are for the Gao's simplified equation under rough ice-covered flow condition. Mathematically, Gao's simplified equation is the most successful of the three equations at calculating scour depth but it does underestimate the extent of scour. In practical terms, this could lead to a false sense of security in practical situations as increased scour depth could lead to premature failure of a pier.

\section{Summary and Conclusion}

Three pier-scour equations, namely the Froehlich design equation, the HEC-18/ Jones equation and Gao's simplified equation, were evaluated against the data from 36 flume experimental runs obtained for open channel, rough and smooth ice-covered flow under uniform bed sediment type. The most important result that can be obtained from the comparison of these three equations is that under nearly the same flow depth and approach flow velocity but different flow cover, the average calculated values from all the three equations stayed nearly constant. On the other hand, in terms of ice cover, the rougher the ice surface, the more turbulent the flow and the deeper the scour depth generated. Although Gao's simplified equation was reasonably successful in prediction of pier scour depth for both the open-channel and smooth-ice conditions, it underestimated the pier-scour depth under rough ice-covered flow conditions. Therefore, it can be concluded that none of the equations adequately model scour depth under rough ice conditions and the equations are in need of another term to make them more suitable to be used for the ice-covered flow conditions.

\section{Acknowledgements}

This work is partially supported by UNBC Research Project Award. Physical experiments were conducted at Quesnel River Research Center (QRRC), Likely, 
BC. We gratefully acknowledge the help provided by QRRC staff.

\section{References}

[1] Warren, L.P. (2011) Scour at Bridges: Stream Stability and Scour Assessment at Bridges in Massachusetts. US Geological Survey.

[2] FHWA (1988) Evaluating Scour at Bridges, NH1-01-001. 4th Edition, Federal Highway Administration, Washington, DC.

[3] Wardhana, K. and Hadipriono, F.C. (2003) Analysis of Recent Bridge Failures in the United States. Journal of Performance of Constructed Facilities, 17, 144-150. https://doi.org/10.1061/(ASCE)0887-3828(2003)17:3(144)

[4] Brandimarte, L., Paron, P. and Di Baldassarre, G. (2012) Bridge Pier Scour: A Review of Processes, Measurements and Estimates. Environmental Engineering \& Management Journal (EEM)), 11.

[5] Brice, J.C. and Blodgett, J.C. (1978) Countermeasures for Hydraulic Problems at Bridges, Federal Highway Administration Report FHWA-RD-78-162.

[6] Liu, H.K., Chang, F.F. and Skinner, M.M. (1961) Effect of Bridge Constriction on Scour and Backwater. Civil Engineering Section, Colorado State University.

[7] Shen, H., Schneider, V.R. and Karaki, S. (1969) Local Scour around Bridge Piers. Journal of the Hydraulics Division, 95, 1919-1940.

[8] Jain, S.C. and Fischer, E.E. (1980) Scour around Bridge Piers at High Flow Velocities. Journal of the Hydraulics Division, 106, 1827-1842.

[9] Melville, B.W. and Sutherland, A.J. (1988) Design Method for Local Scour at Bridge Piers. Journal of Hydraulic Engineering, 114, 1210-1226. https://doi.org/10.1061/(ASCE)0733-9429(1988)114:10(1210)

[10] Froehlich, D.C. (1989) Local Scour at Bridge Abutments. Proceedings of the 1989 National Conference on Hydraulic Engineering, 13-18.

[11] Melville, B.W. (1992) Local Scour at Bridge Abutments. Journal of Hydraulic Engineering, 118, 615-631. https://doi.org/10.1061/(ASCE)0733-9429(1992)118:4(615)

[12] Heza, Y.B.M., Soliman, A.M. and Saleh, S.A. (2007) Prediction of the Scour Hole Geometry around Exposed Bridge Circular-Pile Foundation. Journal of Engineering and Applied Science, 54, 375.

[13] Moore, J.N. and Landrigan, E.M. (1999) Mobilization of Metal-Contaminated Sediment by Ice-Jam Floods. Environmental Geology, 37, 96-101. https://doi.org/10.1007/s002540050365

[14] Sui, J., Wang, J., Yun, H.E. and Faye, K. (2010) Velocity Profiles and Incipient Motion of Frazil Particles under Ice Cover. International Journal of Sediment Research, 25, 39-51. https://doi.org/10.1016/S1001-6279(10)60026-1

[15] Hicks, F. (2009) An Overview of River Ice Problems: CRIPE07 Guest Editorial. Cold Regions Science and Technology, 55, 175-262. https://doi.org/10.1016/j.coldregions.2008.09.006

[16] Hirshfield, F. (2015) The Impact of Ice Conditions on Local Scour around Bridge Piers. Doctoral Dissertation, University of Northern British Columbia.

[17] Wu, P., Balachandar, R. and Sui, J. (2015) Local Scour around Bridge Piers under Ice-Covered Conditions. Journal of Hydraulic Engineering, 142, 04015038. https://doi.org/10.1061/(ASCE)HY.1943-7900.0001063

[18] Richardson, E.V. and Davis, S.R. (1995) Evaluating Scour at Bridges. U.S. Depart- 
ment of Transportation, Federal Highway Administration Hydraulic Engineering Circular 18, Publication FHWA-IP-90-017, 204 p.

[19] Gao, D., Posada, G. and Nordin, C.F. (1993) Pier Scour Equations Used in China. In: Hydraulic Engineering, ASCE, 1031-1036.

[20] Landers, M.N. and Mueller, D.S. (1996) Channel Scour at Bridges in the United States: U.S. Department of Transportation, Federal Highway Administration Publication FHWARD-95-184, $140 \mathrm{p}$.

[21] Brunner, G.W. (2002) HEC-RAS, River Analysis System Hydraulic Reference Manual: U.S. Army Corps of Engineers Report CPD-69, 350 p.

[22] Froehlich, D.C. (1988) Analysis of On-Site Measurements of Scour at Piers. In: Abt, S.R. and Gessler, J., Eds., Hydraulic Engineering-Proceedings of the 1988 National Conference on Hydraulic Engineering, American Society of Civil Engineers, New York, 534-539.

[23] Willmot, C.J. (1981) On the Validation of Models. Physical Geography, 2, 184-194. 